\title{
Severe leptospirosis complicated with multiorgan dysfunction successfully managed with plasma exchange: a case report
}

\author{
Manana Dewage Sankani Vishvara Kularathna*, Senanayake Abeysinghe Mudiyanselage Kularatne, \\ Manoji Pathirage and Pala Thanthirige Madhushi Anuradha Nanayakkara
}

\begin{abstract}
Background: Leptospirosis is a common zoonotic infection caused by the spirochete Leptospira. The disease is more prevalent in the tropics, causing subclinical to severe illness leading to high morbidity and mortality.

Case presentation: A 77-year-old healthy Sri Lankan man presented to the Teaching Hospital Peradeniya with severe leptospirosis complicated with acute kidney injury, pulmonary hemorrhages, myocarditis, and severe thrombocytopenia. He was deteriorating despite treatment with intravenous antibiotics and methylprednisolone boluses. He made a dramatic improvement with two cycles of plasma exchange.
\end{abstract}

Conclusion: Therapeutic plasma exchange is a life-saving treatment modality in severe leptospirosis with multiorgan failure.

Keywords: Leptospirosis, Zoonotic infection, Pulmonary hemorrhages, Myocarditis, Multiple organ failure, Plasma exchange

\section{Introduction}

Leptospirosis is a zoonotic infection. The pathogen is harbored by both wild and domestic farm animals, including rodents, pigs, cattle, and dogs. The pathogenic genus Leptospira interrogans has more than 250 serovars arranged under 23 serogroups [1]. Transmission to humans occurs either by direct contact with infected animal tissue or body fluids, or indirectly from the environment contaminated with the pathogen entering via breaches of the skin or mucosal surface. In Sri Lanka, the farming community has a higher risk of contracting the infection, and even bathing in rivers and lakes, or casual exposure to wet soil carries the risk. After a short incubation period, the infection goes through septicemic and immune phases, causing the clinical manifestations.

*Correspondence: vishvarakularathna@gmail.com

Teaching Hospital Peradeniya, Peradeniya, Sri Lanka
Historically, severe infection with jaundice was known as Weil's disease. However, the clinical severity can vary from subclinical disease to severe multiorgan failure [2]. Thus, the clinical picture of such exotic infection could be similar to most situations of multiorgan dysfunction such as severe malaria, dengue, hantavirus infection, typhoid, rickettsial infections, immunosuppressives, sepsis, and radiation therapy. In Sri Lanka, there are about 3000-5000 suspected cases reported each year, with a case fatality rate of $1-2 \%$, which is significant [3]. This report presents a case of severe leptospirosis successfully managed with plasma exchange. The effectiveness and efficacy of this treatment modality for severe leptospirosis are still under evaluation.

\section{Case presentation}

A previously healthy 77-year-old Sri Lankan Tamil male from Galaha, a laborer at a vegetable farm, presented to the Teaching Hospital Peradeniya with a history of fever original author(s) and the source, provide a link to the Creative Commons licence, and indicate if changes were made. The images or other third party material in this article are included in the article's Creative Commons licence, unless indicated otherwise in a credit line to the material. If material is not included in the article's Creative Commons licence and your intended use is not permitted by statutory regulation or exceeds the permitted use, you will need to obtain permission directly from the copyright holder. To view a copy of this licence, visit http://creativecommons.org/licenses/by/4.0/. The Creative Commons Public Domain Dedication waiver (http://creativeco mmons.org/publicdomain/zero/1.0/) applies to the data made available in this article, unless otherwise stated in a credit line to the data. 
of 1 -week duration. He was apparently well 1 week previously, and presented with high-grade fever along with arthralgia and myalgia. Apart from that, he had generalized headache with the onset of the illness. There were no associated respiratory symptoms, abdominal pain, vomiting, change in bowel habits, or urinary symptoms. He did not have significant past medical, surgical, or family history. He was unmarried and was an occasional alcohol consumer and a nonsmoker.

On examination, he was averagely built, conscious, ill looking, and severely dehydrated. He had cold peripheries. He was icteric, but there was no pallor or conjunctival suffusion. His pulse rate was 112 beats per minute, and his blood pressure was 77/48 $\mathrm{mmHg}$. The abdominal, respiratory, and nervous system examination was unremarkable on admission. noradrenaline infusion $0.6 \mathrm{mcg} / \mathrm{kg} /$ minute. On the following day, patient became anuric for 10 hours with rising creatinine of $414 \mu \mathrm{mol} / \mathrm{L}$. Ultrasound scan of the kidneys showed acute renal parenchymal disease. The patient was started on peritoneal dialysis. On the third day of admission, the patient became dyspneic, and auscultation of the lungs revealed coarse and fine crepitations in the bilateral lung fields. The oxygen saturation dropped even with a continuous positive airway pressure (CPAP) mask, and was $81 \%$. The chest X-ray showed bilateral patchy radio-opaque shadows. The patient was electively intubated, and intensive care was given. The patient was started on intravenous methylprednisolone $1 \mathrm{~g}$ daily for 3 days. The electrocardiogram (ECG)

D3

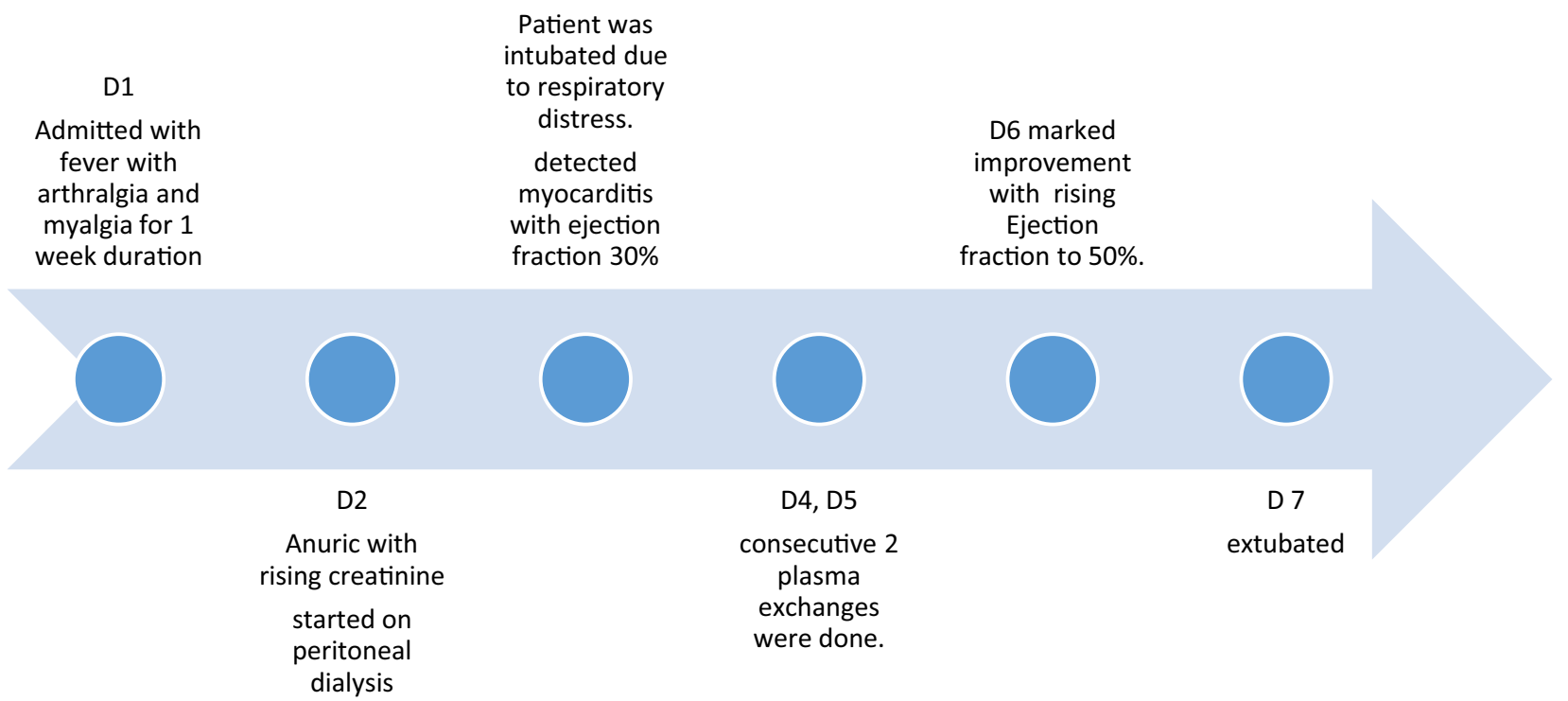

The patients' complete blood count showed white blood cells (WBCs) of $4.46 \times 10^{9} / \mathrm{L}$ (neutrophils $82 \%$, lymphocytes $16 \%)$, platelet count $42 \times 10^{9} / \mathrm{L}$, hemoglobin $(\mathrm{Hb})$ $13 \mathrm{~g} / \mathrm{dL}$, and hematocrit (HCT) of $37 \%$. His C-reactive protein was $345 \mathrm{mg} / \mathrm{L}$, and creatinine was $359 \mu \mathrm{mol} / \mathrm{L}$. Serum bilirubin was $62.9 \mathrm{mmol} / \mathrm{L}$ with direct fraction of $42 \mathrm{mmol} / \mathrm{L}$ and indirect fraction of $21 \mathrm{mmol} / \mathrm{L}$. Arterial blood gases showed $\mathrm{pH} 7.37$, lactate $1.1 \mathrm{mmol} / \mathrm{L}, \mathrm{HCO}_{3}$ $13 \mathrm{mEq} / \mathrm{L}, \mathrm{pCO}_{2} 23 \mathrm{mmHg}, \mathrm{pO}_{2} 95 \mathrm{mmHg}$ (Table 1).

A clinical diagnosis of leptospirosis was made, and the patient was started on intravenous $\mathrm{C}$ penicillin, intravenous ceftriaxone, and oral doxycycline. After adequate fluid resuscitation, the patient was started on intravenous showed widespread $\mathrm{T}$ inversions, and the $2 \mathrm{D}$ echocardiogram showed ejection fraction (EF) of $30 \%$ with left ventricular global hypokinesia. His procalcitonin level was $37.94 \mathrm{ng} / \mathrm{mL}$, and the platelet count was $54 \times 10^{9} / \mathrm{L}$. The patient was started on plasma exchange on the fourth day of admission, and $1840 \mathrm{~mL}$ plasma was removed along with transfusion of $1100 \mathrm{~mL}$ fresh frozen plasma and $1000 \mathrm{~mL}$ normal saline. Six units of platelets, intravenous tranexamic acid, and intravenous vitamin $\mathrm{K}$ were also started. The second plasma exchange was done on the fifth day, with removal of $1810 \mathrm{~mL}$ total plasma volume along with transfusion of $1500 \mathrm{~mL}$ fresh frozen plasma and $250 \mathrm{~mL}$ normal saline. His urine output markedly 
Table 1 Investigations on admission and days later

\begin{tabular}{|c|c|c|}
\hline Investigation & Value & Reference range \\
\hline \multicolumn{3}{|l|}{ Complete blood count } \\
\hline White blood cells & $4.46 \times 10^{9} / \mathrm{L}$ & $3.4-9.6 \times 10^{9} / \mathrm{L}$ \\
\hline Neutrophils & $82 \%$ & $55-70 \%$ \\
\hline Lymphocytes & $16 \%$ & $20-40 \%$ \\
\hline Platelets & $42 \times 10^{9} / \mathrm{L}$ & $150-450 \times 10^{9} / \mathrm{L}$ \\
\hline Hemoglobin & $13 \mathrm{~g} / \mathrm{dL}$ & $13.2-16.6 \mathrm{~g} / \mathrm{dL}$ \\
\hline Hematocrit & $37 \%$ & $38.3-48.6 \%$ \\
\hline C-reactive proteins & & $0-5 \mathrm{mg} / \mathrm{L}$ \\
\hline Day 1 & 345 mg/L & \\
\hline Day 7 & $19 \mathrm{mg} / \mathrm{L}$ & \\
\hline Procalcitonin & $37.94 \mathrm{ng} / \mathrm{mL}$ & $<0.15 \mathrm{ng} / \mathrm{mL}$ \\
\hline Creatinine & & 59-104 $\mu \mathrm{mol} / \mathrm{L}$ \\
\hline Day 1 & $359 \mu \mathrm{mol} / \mathrm{L}$ & \\
\hline Day 2 & $414 \mu \mathrm{mol} / \mathrm{L}$ & \\
\hline Day 7 & $243 \mu \mathrm{mol} / \mathrm{L}$ & \\
\hline Serum bilirubin & $62.9 \mathrm{mmol} / \mathrm{L}$ & $5.1-17 \mathrm{mmol} / \mathrm{L}$ \\
\hline Direct & $42 \mathrm{mmol} / \mathrm{L}$ & $1.7-5.1 \mathrm{mmol} / \mathrm{L}$ \\
\hline Indirect & $21 \mathrm{mmol} / \mathrm{L}$ & $3.4-12 \mathrm{mmol} / \mathrm{L}$ \\
\hline \multicolumn{3}{|l|}{ Arterial blood gas } \\
\hline $\mathrm{pH}$ & 7.37 & $7.35-7.45$ \\
\hline $\mathrm{pO}_{2}$ & $95 \mathrm{mmHg}$ & $75-100 \mathrm{mmHg}$ \\
\hline $\mathrm{pCO}_{2}$ & $23 \mathrm{mmHg}$ & $35-45 \mathrm{mmHg}$ \\
\hline $\mathrm{HCO}_{3}^{-}$ & 13 mEq/L & $22-26 \mathrm{mEq} / \mathrm{L}$ \\
\hline Lactate & $1.1 \mathrm{mmol} / \mathrm{L}$ & $0.1-1 \mathrm{mmol} / \mathrm{L}$ \\
\hline Electrocardiogram & Widespread T inversions & \\
\hline 2D echocardiogram & & EF above $60 \%$ \\
\hline Day 3 & EF 30\%, left ventricular global hypokinesia & \\
\hline Day 6 & EF 50\%, improved left ventricular function & \\
\hline
\end{tabular}

improved, and the peritoneal dialysis was withheld on the following day. Repeat 2D echocardiography showed improved left ventricular function, with ejection fraction of $50 \%$. By the sixth day of admission, the patient's inotrope requirement came down and we planned to wean off from the ventilator. Repeat chest $\mathrm{x}$-ray showed clearing of opacifications in the lungs. The patient was extubated on the seventh day of admission. His serum creatinine came down to $243 \mu \mathrm{mol} / \mathrm{L}$, and C-reactive protein $(\mathrm{CRP})$ was $19 \mathrm{mg} / \mathrm{L}$. Meanwhile, the diagnosis was confirmed as his serology showed positive enzymelinked immunosorbent assay (ELISA) immunoglobulin M (IgM) for leptospirosis. By the tenth day of admission, the patient was discharged with complete recovery. In follow-up, the patient was reviewed after 2 weeks and found to be in good health. 


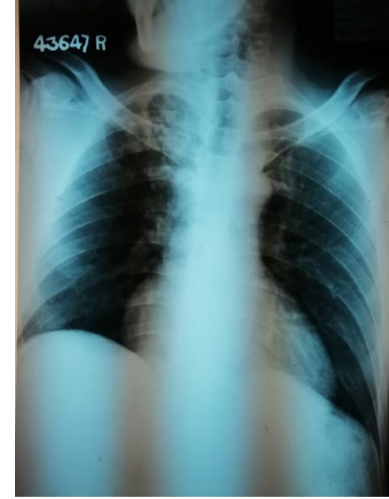

Day 1

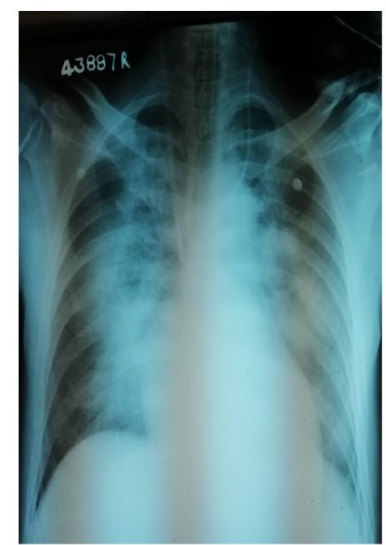

Day 4

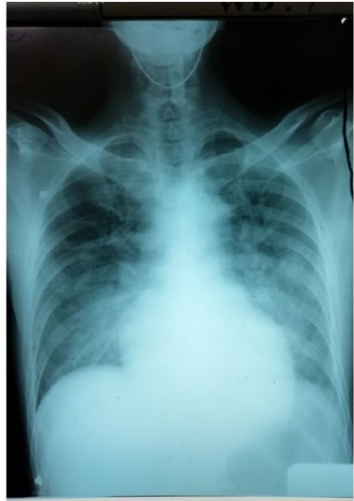

Day 3

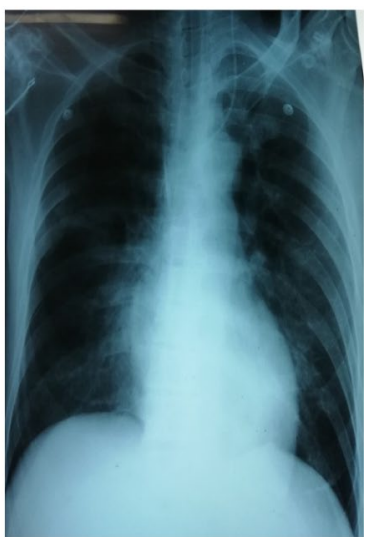

D ay 6- after 2 plasma exchanges

\section{Discussion}

The patient was successfully managed, while deteriorating because of multiorgan failure, with the use of plasma exchange as last resort. The improvement was dramatic with increased EF of the left ventricle, increased urine output, and clearing of lung opacities. Leptospirosis is a commonly encountered zoonotic infection in Sri Lanka. Although many domestic and wild animals are recognized as reservoir hosts for Leptospira, among them, the brown rat (Rattus norvegicus) is recognized as the most important reservoir for human transmission. The pathogen remains dormant in the renal tubules of the reservoir animal and is shed via urine [4]. It is transmitted from animal to human through contact with infected animal urine on the mucous membranes or breaches of the skin [5]. The incubation period is 5-7 days on average [6]. Following penetration into the human body, there are two phases: the septicemic and immune phases [7]. During the septicemic phase, the patient has abrupt-onset fever, arthralgia, and myalgia, and Leptospira can be isolated from blood. Then, there will be a temporary settlement of symptoms before entering the immune phase. During the immune phase, there is a humoral response that causes clearance of the organism from most tissues [2]. During this phase, deposition of immune complexes will cause endothelial damage [2].

Our patient is a vegetable farmer and had a high risk of exposure to leptospirosis. Also, he presented with a clinical picture suggestive of leptospirosis and later became positive for ELISA IgM of leptospirosis, confirming the diagnosis according to World Health Organization (WHO) guidelines [6]. The patient had multiorgan failure with acute kidney injury, pulmonary hemorrhages, myocarditis, and hematological involvement with thrombocytopenia. Apart from routine usage of antibiotics, the patient was started on intravenous methylprednisolone $1 \mathrm{~g}$ daily for three consecutive days without success. After two cycles of plasma exchange on two consecutive days, the patient made a dramatic improvement from organ failure within only a few days.

Intravenous methylprednisolone is used to treat severe leptospirosis based on the immune-mediated pathogenesis of the disease, and it has been shown to be beneficial to reduce mortality [8]. The recommended dose used in Sri Lanka is intravenous methylprednisolone $1 \mathrm{~g}$ daily for 3 days. Early usage of methylprednisolone within 12 hours of onset of symptoms improved the outcome of the disease and reduced or delayed the need for mechanical ventilation [3]. Several case series and case reports have shown the benefit of steroid usage in severe leptospirosis. A Sri Lankan study of 227 patients in pre- and post-methylprednisolone periods demonstrated a significant reduction of death rates in the post-methylprednisolone group compared with the pre-methylprednisolone group (21.8\% and $10.7 \%$, respectively.) [8]. The benefit is more pronounced if given early in the multiorgan dysfunction [8]. A systemic review of usage of high-dose steroids in severe leptospirosis identified four studies with beneficial effects and one study that showed harmful effects leading to nosocomial infections [9].

Tissue damage will occur during the severe sepsis phase of leptospirosis because of systemic inflammation. Also, there will be tissue destruction due to immune complex-mediated mechanisms in the immune phase of the disease. Apart from that, with the usage of antibiotics, the release of an excessive amount of endotoxins by the organism's death also contributes to the immune pathogenic process (Jarisch-Herxheimer reaction) [10]. Plasma exchange will minimize the tissue damage caused by the above mechanisms [11]. Also, there are beneficial effects by removing circulatory endotoxins, catabolic products, and inflammatory markers with the plasma exchange [12]. Additionally, high bilirubin levels occur in leptospirosis compared with the aminotransferase levels, 
as a result of impaired excretion of bilirubin caused by microcirculatory abnormalities and biliary obstruction [13]. High bilirubin levels in leptospirosis can cause toxic effects on the renal tubules leading to acute kidney injury. Therefore, removing bilirubin using plasma exchange has demonstrated rapid clinical response in severe leptospirosis [13].

The efficacy of plasma exchange was evaluated at the Teaching Hospital Karapitiya in Sri Lanka. A study of 53 patients with serologically confirmed complicated leptospirosis demonstrated a mortality rate of $36.4 \%$ in the therapeutic plasma exchange (TPE) only group, $21.4 \%$ in the intravenous immunoglobulin and therapeutic plasma exchange group, and $92.8 \%$ in the group that was given neither of these two therapies. Therefore, TPE showed a significant reduction of mortality in patients with severe leptospirosis complicated with multiorgan failure [14]. A few other case reports and studies demonstrated the beneficial effects of plasma exchange in severe leptospirosis. Trivedi et al. conducted a case series of 144 patients with serologically confirmed leptospirosis with mild pulmonary hemorrhages. Of them, 114 patients received two consecutive plasma exchanges followed by one dose of cyclophosphamide, while the rest were treated with symptomatic management. In the treatment group, $64.4 \%$ survived compared with the untreated group where the survival rate was $16.6 \%$ [5]. A 67-yearold patient with complicated leptospirosis was successfully treated with plasma exchange by Taylor et al. and demonstrated that plasma exchange plays an important role in recovery [11]. Kai-Chung Tse et al. applied plasma exchange to treat leptospirosis complicated with hyperbilirubinemia and renal failure and reported a rapid clinical recovery [13].

\section{Conclusion}

We observed the survival benefit of therapeutic plasma exchange in multiple organ failure in severe leptospirosis. The plasma exchange would have reduced the systemic inflammation and the tissue damage caused by immune complex-mediated mechanisms in leptospirosis. More robust research studies are needed in the future to study the efficacy and effectiveness of plasma exchange in complicated leptospirosis.

\section{Acknowledgements}

Not applicable.

\section{Authors' contributions}

All authors examined, assessed, and were involved in the management of the patient. All authors read and approved the final manuscript.

\section{Authors' information}

Vishvara Kularathna and Madhushi Nanayakkara are registrars in general medicine in the professorial medical unit of teaching hospital Peradeniya, Sri Lanka. S.A.M. Kularatne is the Professor of Medicine, Faculty of Medicine, University of Peradeniya. Manoji Pathirage is a professor in medicine in the same department.

\section{Funding}

There is no source of funding.

Availability of data and materials

Data sharing is not applicable to this article as no datasets were generated or analyzed during the current study.

\section{Declarations}

Ethics approval and consent to participate

Not applicable

\section{Consent for data collection and publication}

Written informed consent was obtained from the patient for publication of this case report and any accompanying images. A copy of written consent is available for review by the Editor-in-Chief of this journal.

\section{Competing interests}

The authors declare that they have no competing interests.

Received: 19 August 2021 Accepted: 30 September 2021

Published online: 13 December 2021

\section{References}

1. Dutta TK, Christopher M. Leptospirosis_an overview. 2005;53(June).

2. Sheet F. Leptospirosis.

3. Oludele J, Lesko B, Mahumane Gundane I, de Bruycker-Nogueira F, Muianga A, Ali S, Mula F, Chelene I, Falk KI, Barreto Dos Santos FGE. National guidelines on management of leptospirosis. Vol. 5; 2017. https://doi.org/10.4269/ajtmh.17-0317

4. Haake DA, Levett PN. Leptospirosis in humans. Curr Top Microbiol Immunol. 2015. https://doi.org/10.1007/978-3-662-45059-8_5.

5. Trivedi SV, Vasava AH, Bhatia LC, Patel TC, Patel NK, Patel NT. Plasma exchange with immunosuppression in pulmonary alveolar haemorrhage due to leptospirosis. Indian J Med Res. 2010;131:429-33.

6. WHO. Human leptospirosis: guidance for diagnosis, surveillance and control. Geneva: World Health Organization; 2003. p. iii.

7. De Brito T, da Silva AMG, Abreu PAE. Pathology and pathogenesis of human leptospirosis: a commented review. Rev Inst Med Trop Sao Paulo. 2018. https://doi.org/10.1590/S1678-9946201860023.

8. Kularatne SAM, Budagoda BDSS, De Alwis VKD, et al. High efficacy of bolus methylprednisolone in severe leptospirosis: a descriptive study in Sri Lanka. Postgrad Med J. 2011. https://doi.org/10.1136/pgmj.2009. 092734.

9. Soc TR, Med T, Rodrigo C, et al. High dose corticosteroids in severe leptospirosis: a systematic review. Trans R Soc Trop Med Hyg. 2014. https://doi.org/10.1093/trstmh/tru148.

10. Bourquin V, Ponte B, Hirschel B, Pugin J, Martin P-Y, Saudan P. Severe leptospirosis with multiple organ failure successfully treated by plasma exchange and high-volume hemofiltration. Case Rep Nephrol. 2011. https://doi.org/10.1155/2011/817414.

11. Reports C, Taylor D, Karamadoukis L. Plasma exchange in severe leptospirosis with multiorgan failure: a case report. J Med Case Rep. 2013;7(1):1. https://doi.org/10.1186/1752-1947-7-169.

12. Cerdas-quesada C. Potential benefits of plasma exchange by apheresis on the treatment of severe icteric leptospirosis: case report and literature review q. Transfus Apheresis Sci. 2011;45:191-4. https://doi.org/10. 1016/j.transci.2011.07.012. 
13. KaiChung T, PokSiu Y, KingMen H, et al. Potential benefit of plasma exchange in treatment of severe icteric leptospirosis complicated by acute renal failure. Clin Diagn Lab Immunol. 2002;9:482-4.

14. Fonseka CL, Lekamwasam S. Role of plasmapheresis and extracorporeal membrane oxygenation in the treatment of leptospirosis complicated with pulmonary hemorrhages. J Trop Med. 2018. https://doi.org/ $10.1155 / 2018 / 4520185$

\section{Publisher's Note}

Springer Nature remains neutral with regard to jurisdictional claims in published maps and institutional affiliations.

- fast, convenient online submission

- thorough peer review by experienced researchers in your field

- rapid publication on acceptance

- support for research data, including large and complex data types

- gold Open Access which fosters wider collaboration and increased citations

- maximum visibility for your research: over 100M website views per year

At BMC, research is always in progress.

Learn more biomedcentral.com/submissions 